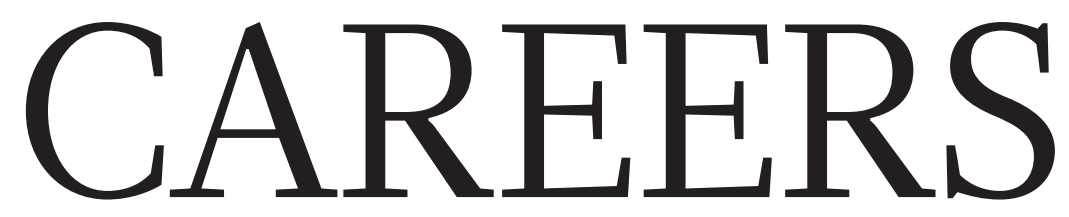

NATUREJOBS FACEBOOK Science-career posts, jobs, advice www.facebook.com/naturejobs

BLOG Stories and counsel for workplace support blogs.nature.com/naturejobs
NATUREJOBS For the latest career listings and advice www.naturejobs.com

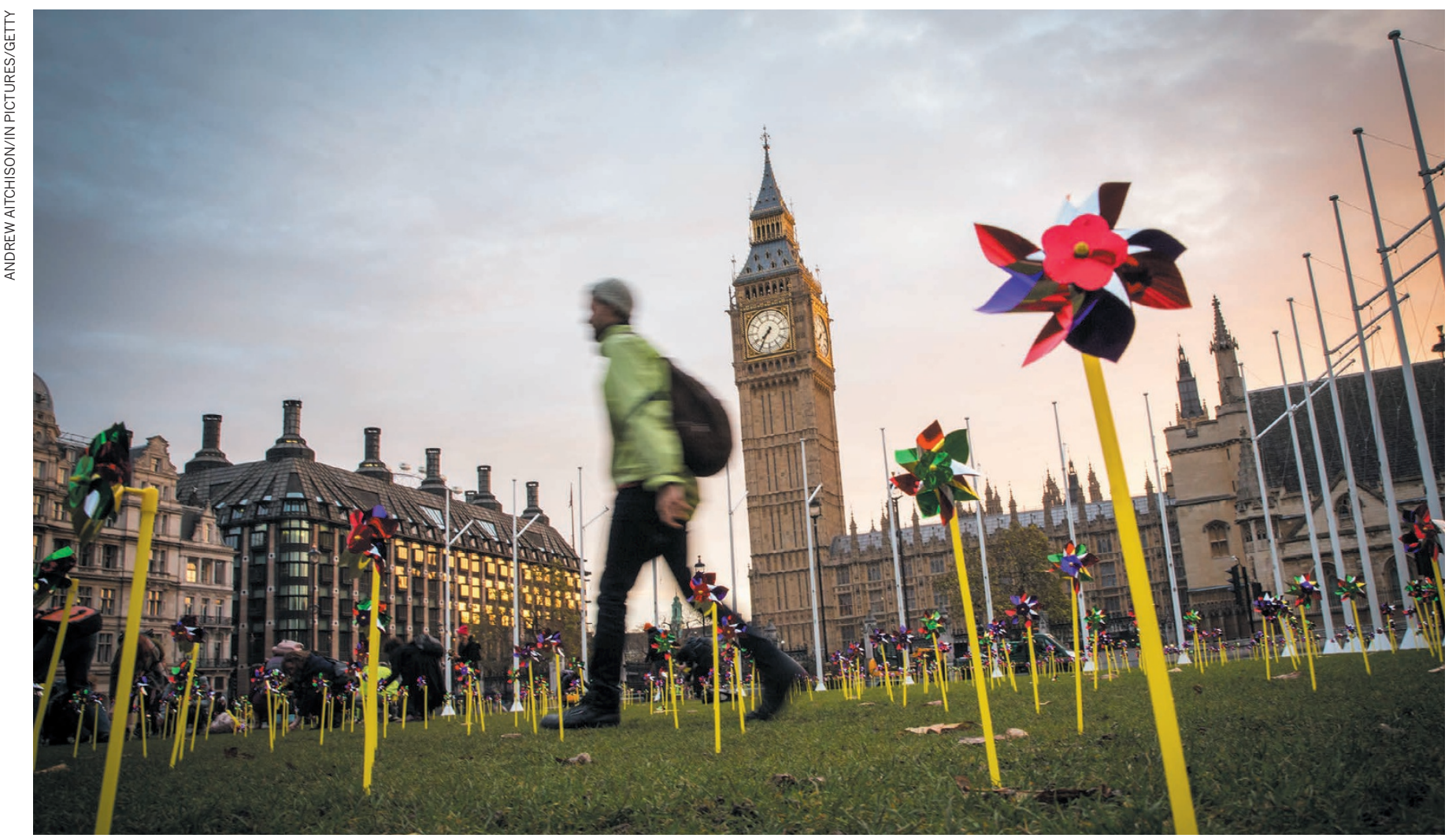

Scientists need to step forward if they are to ensure that politicians understand the importance of their work.

\title{
SCIENCE ADVOCACY
}

\section{Get involved}

\section{Presenting science to politicians in a way they can understand can have good outcomes.}

$\mathrm{W}$

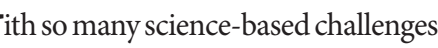
facing the world, researchers who can help to inform and affect policy can have an outsized impact. We asked Connie Lee, Tamara Galloway and Niklas Höhne to describe how they have helped to shape government policy - and how others can learn from their experiences.

As chair of the public-policy committee for the American Society for Cell Biology (ASCB), Lee is a prominent advocate for science. She studied mammalian mitochondria before becoming an editor of The EMBO Journal and a deputy editor of Cell. As assistant dean for basic science at the University of Chicago in Illinois, she helps to oversee nine science departments.

After training as a physicist, Höhne turned his attention to climate change, a field in which he hoped to make a global difference. As a founding partner of the New Climate Institute in Cologne, Germany, and a professor of greenhouse-gas mitigation at Wageningen University in the Netherlands, he works at the intersection of science and policy.

Galloway, an ecotoxicologist at Exeter University, UK, can say with certainty that her research - and her advocacy - have brought real-world results. Her testimony in front of Parliament in May helped to bring about a UK ban on microplastics in personal-care products, an important source of marine pollution. In June, she discussed her research on pollutants in front of a committee of the United Nations in New York City.

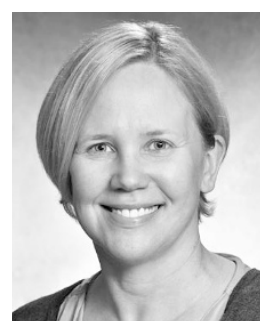

FIGHT FOR BASICSCIENCE FUNDING

Connie Lee, assistant dean for basic science at the University of Chicago in Illinois

Scientists have a lot of demands on their time. But getting involved in policy and advocacy is extremely important. Politicians hear from many lobbyists. If they don't hear from scientists too, we might be left out.

I got bitten by the policy bug in 2008 
when I visited Capitol Hill, the home of the US Congress, as a representative of the ASCB. My dream is for every US scientist to visit Capitol Hill - you never know what questions politicians are going to ask. We met staff and elected members of Congress, and they had so many misunderstandings about science. A lot of people think that National Institutes of Health (NIH) funding only affects people in Bethesda, Maryland, where the NIH is headquartered. They don't realize that the funding spreads out to all 50 states, supporting research and creating jobs.

The lack of scientific understanding among policymakers can be frustrating. Members of the US House of Representatives will scan titles of NIH grants to find items that sound wasteful. These grants have been peer reviewed, but the politicians just look at the titles and take them out of context. It can be important work, but it's mocked and dismissed. We can't let that sort of thing get us down.

There's a communication gap between scientists and politicians. Scientists have to learn to explain the importance of their own work, whether they're talking to a policymaker, a dean or a potential donor. But we have to share a bigger message, too. We need to advocate for the institution of science and the importance of funding basic science. You never know where basic research can lead. The methodology behind CRISPR was discovered by looking at how bacteria protect themselves. Now it's used to edit genomes.

The ASCB lobbies for issues outside the lab, such as immigration and the importance of international collaboration. We want to make sure junior researchers from other countries receive visas that last long enough to allow them to get the training they need.

Policy and advocacy can take as much time as you're willing to give it. A lot of scientific societies have outreach positions, which is a great place to get started. You can join a government-relations board at your university or just offer a tour of your lab whenever a politician visits. And when you do get a grant funded, write to your local senator or representative and thank them for supporting science. It's baby steps, but we need to build relationships so they can see us as a resource.

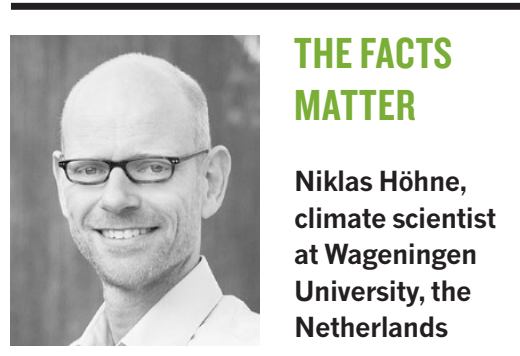

Science covers the questions at the heart of society's problems. When it comes to climate change, it's absolutely essential that the research community helps to translate science into options for policymakers.

I study international climate negotiations, such as the Paris agreement of 2015. The stated aim of the agreement was to limit warming to $1.5^{\circ} \mathrm{C}$ above pre-industrial levels. It requires much analysis to look at each country's emission proposals and then add them up to see whether they are on track to meet the overall goal. As I reported in November at the climate-change conference in Marrakesh, Morocco, our models show that some countries' current emissions proposals aren't sufficient to reach the Paris goal. Policymakers need this information so that they can adjust their country's emission targets, if they have the will to do so.

I would say that most governments are generally well-informed about climate change. The goal to limit warning to $1.5^{\circ} \mathrm{C}$ is stronger than the previous one of $2^{\circ} \mathrm{C}$, and that's because politicians understood the evidence. Scientists were able to show that a $2{ }^{\circ} \mathrm{C}$ rise wouldn't be safe for the planet.

Some politicians, including the presidentelect of the United States, have denied that climate change exists. If individual politicians don't want to be convinced, there's not much more that scientists can do. Still, it's important to keep gathering data and reaching out to policymakers and the general public. The scientific community has a duty to continue to provide evidence and explain what we really know about human-caused emissions and global temperatures.

Every 6 years, for example, about 2,000 researchers work together to create a report for the Intergovernmental Panel on Climate Change on the current situation. It is a technical report that most politicians would have trouble understanding. But scientists can explain the key points and the take-home messages. Without that translation, their research won't have much of an impact.

In some parts of society, we seem to be moving to an era beyond factual argument. Emotion seems to matter more than the facts. We have total access to information, but we also have total access to misinformation. Scientists have to make the facts matter again. We can do that by communicating results in an accessible way.

I have been doing this for 20 years, and there have been a lot of setbacks. But I'm still hopeful. I got into climate change because I wanted to have an impact on the world, and I still think climate scientists can accomplish that. Despite the challenges, controlling climate change is doable. We have the technology we need to reach the goals. My main motivation is to give politicians the tools that they need to get this right. Progress may be slower than I hoped, but we'll see how things work out.

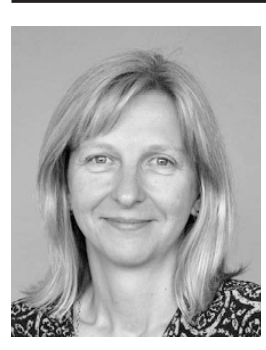

\section{DELIVER YOUR MESSAGE}

\author{
Tamara Galloway, \\ ecotoxicologist at \\ Exeter University, UK
}

The UK government is full of people who used to be bankers and lawyers. There's a great lack of scientific understanding. Most scientists aren't interested in becoming politicians, but it's still possible for them to become involved and inform policy.

As a scientist, I always wondered why it took government so long to act on issues, especially when the evidence was already clear. Then, in November 2015, I participated in the Royal Society's 'Week in Parliament' scheme, and spent a week in London shadowing a Member of Parliament (MP). It was an amazing experience, and it helped me to understand that government is a giant monolith. Change comes slowly - in most cases.

In May, I and two other environmental scientists addressed a parliamentary select committee of MPs on marine pollution caused by microplastics, spheres of plastic less than $5 \mathrm{~mm}$ in diameter. The committee had three hours to ask us any question they wanted, and we didn't know what to expect. I felt like I'd had been called into the headmaster's office.

The committee members asked intelligent and well-informed questions, trying to put everything in context. There's a lot of hysteria on the topic and websites with false information, so I needed to provide impartial scientific evidence. You don't want to sound as if you're pushing an agenda. I explained that microplastics, which are often found in cosmetics and shampoos, aren't actually toxic, but that they can disrupt the feeding and reproduction of many marine organisms.

Shortly after the hearing, the committee announced that microplastics will be banned from personal-care products in the United Kingdom by the end of 2017. The science we were doing had had a real impact, and I was amazed that it happened so quickly.

The pinnacle of my policy outreach - so far - is when I spoke about my research in front of a United Nations panel in New York in June. After that, I felt I could tackle anything.

The lesson for me is that we must speak up. Scientists tend to become more and more specialized, to the point where it can be difficult to talk to other researchers, let alone the general public. I use my children as a sounding board. If they understand, I know I'm ready.

\section{INTERVIEWS BY CHRIS WOOLSTON}

These interviews have been edited for clarity and length. 